\title{
Histological study of chronic gastritis from the United Arab Emirates using the Sydney system of classification
}

\author{
A M Zaitoun
}

\begin{abstract}
Aims-To determine the prevalence of Helicobacter pylori in five main nationality groups with gastric ulcer, duodenal ulcer, and non-ulcer dyspepsia; and to determine the histopathological types of gastritis and assess the graded variables of Helicobacter associated gastritis.

Methods-Gastric antral and corpus biopsy specimens from 437 patients were examined for the prevalence of $H$ pylori, 337 of which were classified and graded histologically according to the Sydney system.
\end{abstract}

Results-The overall colonisation rate of $H$ pylori was $90 \%$, and there was no significant difference between groups of different ethnic origins. The colonisation rates were $99 \%, 89 \%$, and $78 \%$ in patients with duodenal ulcer, non-ulcer dyspepsia, and gastric ulcer, respectively. Helicobacter associated gastritis was the most common form of chronic gastritis (87\%). H pylori density was greater in the antrum than the body. Gastric atrophy in helicobacter associated gastritis was seen in $54 \%$ of the cases (43\% grade I, $10 \%$ grade II, $1 \%$ grade III) and increased the older the patients. Atrophy of the corpus alone was very rare (1\%). Atrophy and intestinal metaplasia were more prevalent in patients with gastric ulcer than duodenal ulcer.

Conclusion-The colonisation rate of $H$ pylori was similar in the five groups studied and was almost invariably present in gastric biopsy specimens in patients with duodenal ulcer. $H$ pylori associated gastritis was the most common form of gastritis: Atrophy was mainly of low grade and increased the older the patient.

(F Clin Pathol 1994;47:810-815)

Department of Histopathology, Al Quassimi Hospital, Sharjah, UAE A M Zaitoun

Correspondence to: Dr Zaitoun, Department of Histopathology, Mayday Healthcare NHS Trust, Mayday Road, Thornton Heath, Surrey CR7 7YE Accepted for publication 9 February 1994 dren below the age of 12 years. ${ }^{8}$ tries acquisition of $H$ pylori occurs at
The prevalence of $H$ pylori in gastric mucosa from patients with ulcer and nonulcer dyspepsia has also been studied. ${ }^{9}$ However, studies concerning the colonisation rate of $H$ pylori in gastric biopsy specimens and its role in gastritis and peptic ulceration in patients from Middle Eastern countries are still few in number. ${ }^{10-12}$

There are several classifications for chronic gastritis: morphological ${ }^{13-14}$; topographical ${ }^{15-16}$, and combined morphological and topographical. ${ }^{17}$ The discovery of $H$ pylori as a major cause of gastritis has led many authors to incorporate aetiology in the classification of chronic gastritis. ${ }^{18-20}$ The Sydney system of classification of chronic gastritis has incorporated topography, morphology, and aetiology in one system. ${ }^{21}$

This system recognises acute, chronic, and special forms of chronic gastritis, permitting differentiation of distinct entities previously classified together under chronic gastritis. The most important characteristic of this system is its grading of five main histological features of gastritis, which allows the changes that occur in gastric mucosa to be assessed accurately. ${ }^{21}$

The aims of this study were to assess the colonisation rate of $H$ pylori in gastric biopsy specimens from patients with peptic ulcers and non-ulcer dyspepsia in five main population groups currently living in the United Arab Emirates (UAE). The Sydney system was also applied to the material studied, and the graded variables in Helicobacter associated gastritis were assessed quantitatively.

\section{Methods}

In this study 437 patients with ulcer and nonulcer dyspepsia attending five gastroenterology clinics in the northern region of the UAE were studied during December 1990 to May 1992. The mean age was 36.8 years (range 12-100 years) and 152 were female. Only patients with histological evidence of gastritis were included. Patients taking antibiotics before endoscopy over a period of at least six weeks and those with malignant diseases were excluded.

Patients were categorised into five main nationality groups:

group 1 nationals of the UAE and some other neighbouring countries;

group 2 nationals of India, Pakistan, and Sri Lanka;

group 3 nationals of Bangladesh; 
Figure 1 Gastric biopsy specimen of the antrum showing mild atrophy represented by some loss of the gland in a background of mild inflammation

(haematoxylin and eosin).

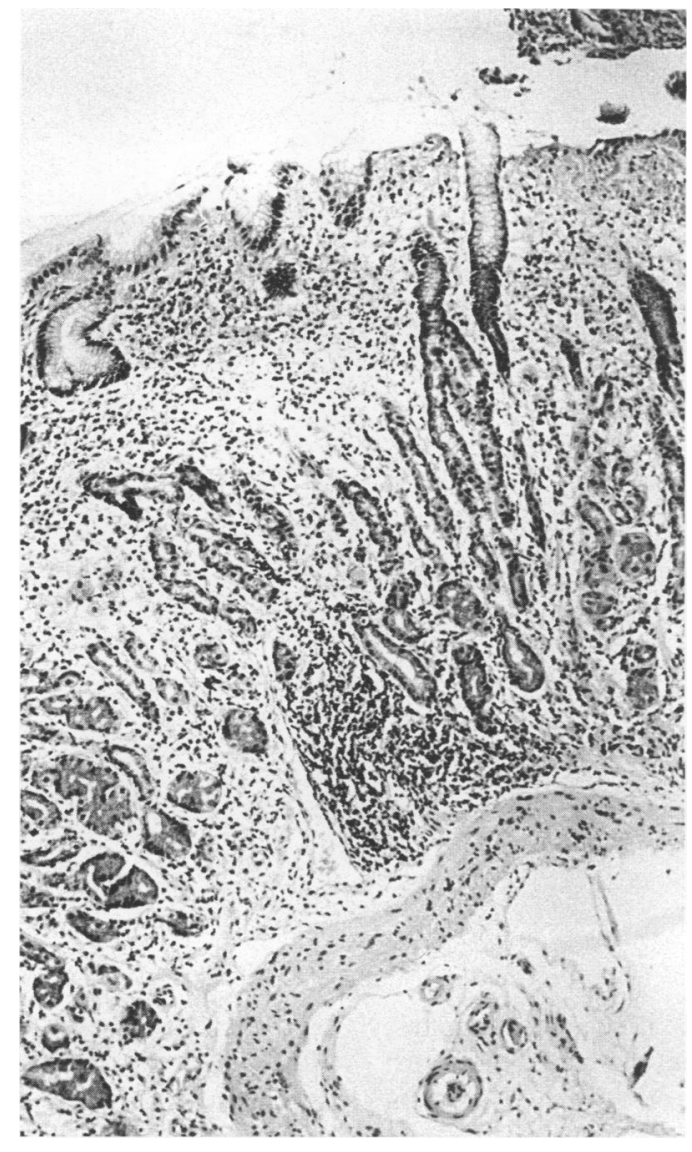

Figure 2 Gastric biopsy specimen of the antrum showing moderate atrophy with more loss of gland in a background of mild inflammation and grade I intestinal metaplasia ( $A B / P A S$ stain).

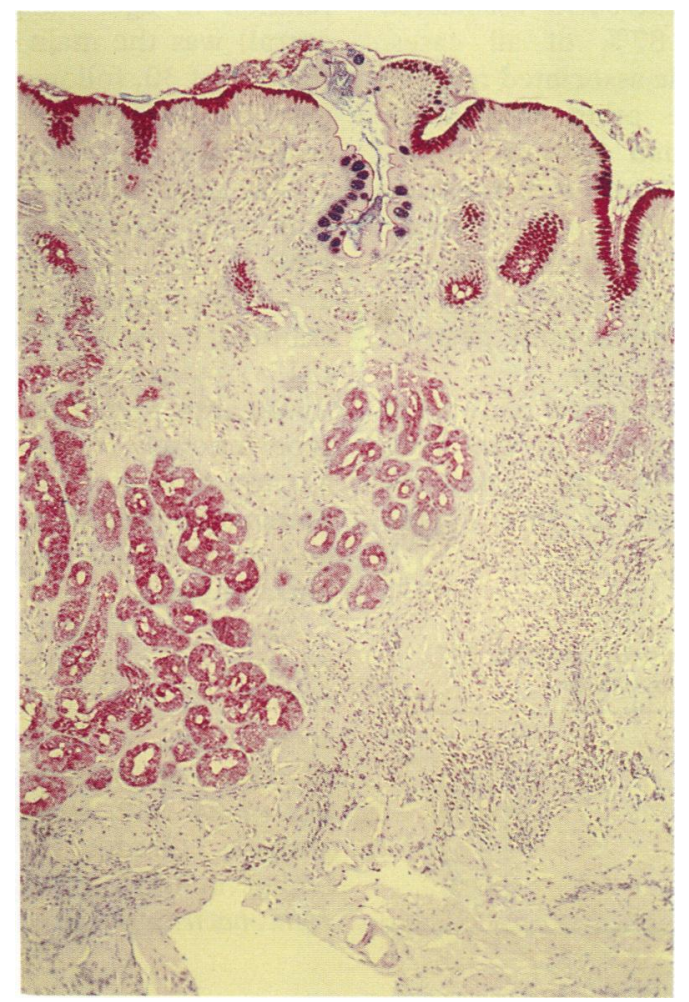

group 4 nationals of Iraq, Iran, and countries north of Saudi Arabia;

group 5 nationals of the following three African countries-Egypt, Sudan, and Somalia.
All non-UAE patients were born in their original countries and had been resident in the UAE for a period of one to 20 years.

Patients were also grouped under three clinical conditions: non-ulcer dyspepsia, duodenal ulcer, and gastric ulcer.

Biopsy specimens were fixed in $10 \%$ formalin and routinely processed. Paraffin wax sections were cut at three levels of $4 \mu \mathrm{m}$ in thickness and stained with haematoxylin and eosin, Diff- $3,^{22}$ and alcian blue/periodic acidSchiff (AB/PAS) stains. All slides were examined for the presence of $H$ pylori. Slides from 337 patients were graded according to the Sydney system. ${ }^{21}$ The remaining 100 biopsy specimens were superficial and used only to study the prevalence of $H$ pylori. Graded variables were $H$ pylori density, inflammation, activity, atrophy (figs 1-3) and intestinal metaplasia.

Reproducibility of grading was assessed blind by examining eight gastric biopsy specimens on 12 different occasions. The coefficient of variations (CV) for all graded variables in both antrum and body mucosa were: $0 ; 4.21 ; 4.76 ; 4.95 ; 5.10 ; 6.05 ; 6.41$; and 6.64. Biopsy specimens with a small number of lymphocytes were considered normal apart from bile associated gastritis..$^{23}$ One or more aggregates of lymphocytes within the lamina propria with or without lymphoid follicles were regarded as significant.

The criteria described by other authors were used for the diagnosis of bile associated reactive gastritis, ${ }^{23}$ drug associated reactive gastritis, ${ }^{24}$ and lymphocytic gastritis..$^{25}$

Differences were evaluated for significance using the $\chi^{2}$ test with the Yates' correction, and results were considered significant if $\mathrm{p}<0.05$ (two tailed probability) was reached.

\section{Results}

The colonisation rate of $H$ pylori in gastric biopsy specimens from all 437 patients, in relation to the five different ethnic groups and three clinical conditions, is shown in table 1. The difference in the colonisation rates among all the groups was not significant and the overall prevalence was $90 \%$. The colonisation rate was $99 \%$ in patients with duodenal ulcer, $89 \%$ in patients with non-ulcer dyspepsia, and $78 \%$ in those with gastric ulcer. The difference was significant between

Table 1 Prevalence of $H$ pylori in 437 patients with ulcer and non-ulcer dyspepsia in relation to five main nationality groups and clinical diagnosis

\begin{tabular}{lrrl}
\hline & $\begin{array}{l}\text { Total } \\
\text { No of } \\
\text { patients }\end{array}$ & $\begin{array}{l}\text { Total } \\
\text { positive }\end{array}$ & Percentage \\
\hline Group I (UAE) & 151 & 141 & $93 \cdot 38$ \\
Group II (India) & 29 & 113 & $87 \cdot 60$ \\
Group III (Bangladesh) & 42 & 38 & $90 \cdot 48$ \\
Group IV (Jordan, Iraq, & 61 & 56 & $91 \cdot 80$ \\
Iran) & 54 & 47 & $87 \cdot 04$ \\
Group V (Africa) & 315 & 279 & $88 \cdot 57^{\star}$ \\
Non-ulcer dyspepsia & 99 & 98 & $98 \cdot 99 \dagger$ \\
Duodenal ulcer & 23 & 18 & $78 \cdot 26 \ddagger$ \\
Gastric ulcer & 437 & 395 & $90 \cdot 39$ \\
Total & & & \\
\hline
\end{tabular}

$\mathrm{p}$ value ${ }^{\star} v+\mathrm{p}<0.0015$

$\dagger v \ddagger \mathrm{p}<0.0001$ 
Figure 3 Gastric biopsy specimen of the antrum showing severe atrophy. Only a few normal glands remain in a background of mild inflammation and grade I intestinal metaplasia (haematoxylin and eosin).

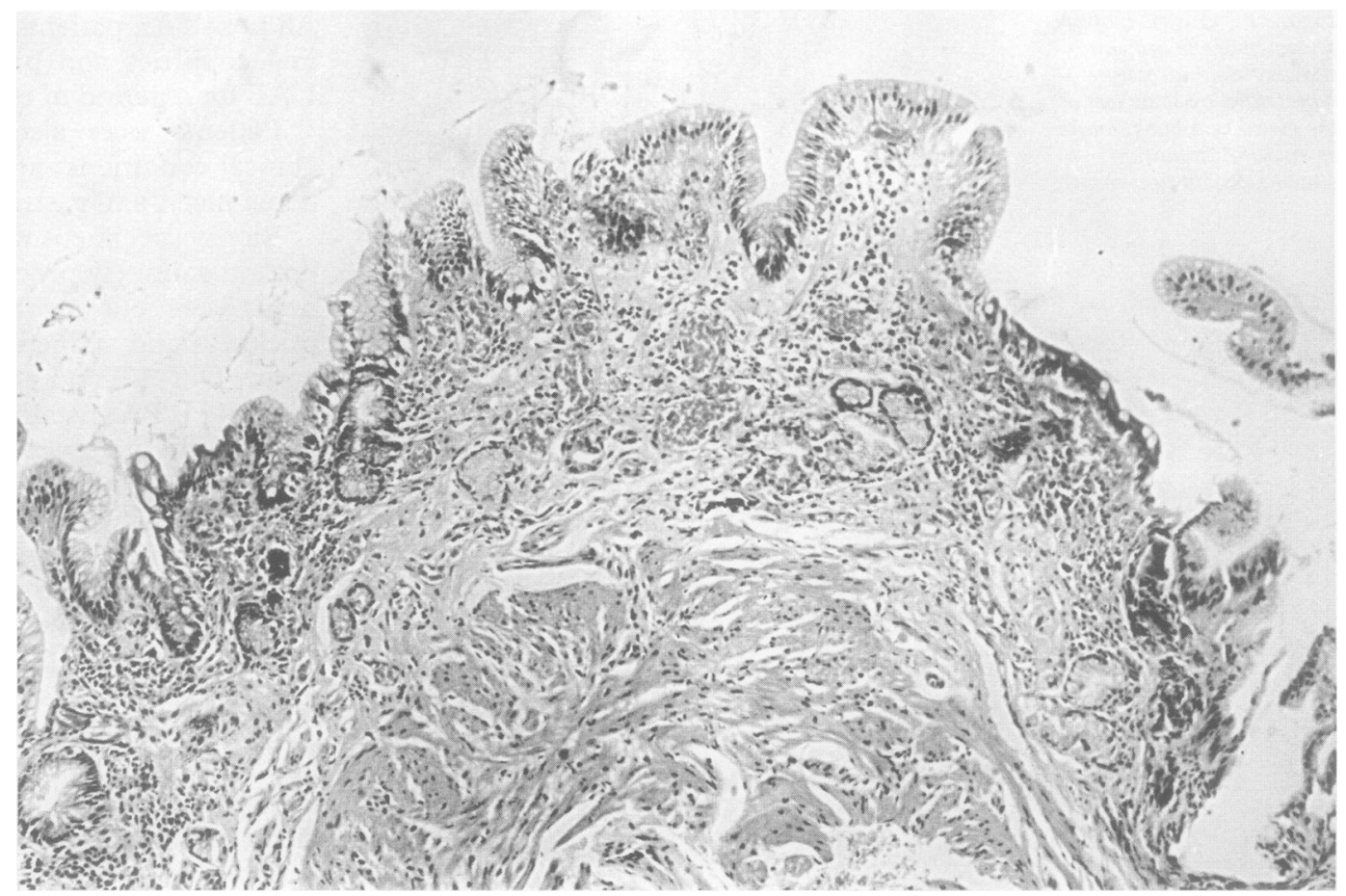

patients with duodenal ulcer and gastric ulcer $(p<0.0001)$ and between patients with duodenal ulcer and non-ulcer dyspepsia $(\mathrm{p}<0.0015)$.

The histological forms of chronic gastritis are shown in table 2. Helicobacter associated gastritis accounted for $87 \%$ of all cases. Idiopathic gastritis and bile associated reactive gastritis represented the other two major groups. Four patients had mucosal injury caused by non-steroidal anti-inflammatory drugs (NSAIDS), aspirin, and alcohol. Lymphocytic gastritis was seen in two patients who were also positive for $H$ pylori (table 2). One patient showed granulomatous gastritis and was also positive for $H$ pylori.

Table 3 shows the topographical patterns of Helicobacter associated gastritis in the three groups of patients: pangastritis (predominantly antral) was present in $54 \%$ of the

Table 2 Histological forms of chronic gastritis in 337 patients with ulcer and non-ulcer dyspepsia

\begin{tabular}{llc}
\hline Gastritis & No (\%) of cases \\
\hline 1 & Helicobacter associated & $294(87 \cdot 2)$ \\
2 & Idiopathic & $24(7 \cdot 1)$ \\
3 & Bile associated reactive & $12(3 \cdot 6)$ \\
4 & Drug associated reactive & $4(1 \cdot 2)$ \\
5 & Lymphocytic & $2(0 \cdot 6)$ \\
6 & Granulomatous & $1(0 \cdot 3)$ \\
\hline
\end{tabular}

patients, followed by pangastritis (35\%), antral gastritis $(10 \%)$, and pangastritis (predominantly corporal) (1\%).

Figure 4 shows the three main topographical patterns of Helicobacter associated gastritis in relation to age. Pangastritis (predominantly antral) was the main pattern in patients over the age of 30, followed by pangastritis. Antral gastritis was the main pattern in patients under 20 years of age.

The distribution of $H$ pylori in antral type and body type gastric mucosa is shown in table 4. One hundred and sixty four out of 294 (56\%) patients had $H$ pylori equally distributed between antrum and corpus. In 92 (31\%) patients, the $H$ pylori grade was predominantly higher in antral mucosa than body type mucosa. $H$ pylori was identified in the antrum only in $19(6 \%)$ patients. Two (1\%) patients showed $H$ pylori in the corpus only and atrophy and intestinal metaplasia in the antral mucosa.

Grades of atrophy in $H$ pylori associated gastritis and idiopathic gastritis are shown in table 5. Chronic gastritis without atrophy was seen in 134 out of 294 (46\%) patients with $H$ pylori associated gastritis compared with 10 out of $24(42 \%)$ of patients with idiopathic gastritis. Grades II and III atrophy were higher in idiopathic gastritis compared with Helicobacter associated gastritis.

Table 3 Topographical patterns of Helicobacter associated gastritis in 2.94 patients with ulcer and non-ulcer dyspepsia

\begin{tabular}{|c|c|c|c|c|c|c|c|c|c|}
\hline $\begin{array}{l}\text { Clinical } \\
\text { condition }\end{array}$ & $\begin{array}{l}\text { Total } \\
\text { No }\end{array}$ & Pangastritis & Percentage & $\begin{array}{l}\text { Pangastritis } \\
\text { predominantly } \\
\text { antral }\end{array}$ & Percentage & $\begin{array}{l}\text { Pangastritis } \\
\text { predominantly } \\
\text { corporal }\end{array}$ & Percentage & $\begin{array}{l}\text { Antral } \\
\text { gastritis } \\
\text { only }\end{array}$ & Percentage \\
\hline $\begin{array}{l}\text { Non-ulcer } \\
\text { dyspepsia } \\
\text { Duodenal ulcer } \\
\text { Gastric ulcer } \\
\text { Total } \\
\text { Percentage }\end{array}$ & $\begin{array}{r}197 \\
79 \\
18\end{array}$ & $\begin{array}{r}73 \\
26 \\
3 \\
102 \\
35\end{array}$ & $\begin{array}{l}37 \\
33 \\
17\end{array}$ & $\begin{array}{r}102 \\
44 \\
13 \\
159 \\
54\end{array}$ & $\begin{array}{l}52 \\
56 \\
72\end{array}$ & $\begin{array}{l}4 \\
0 \\
0 \\
4 \\
1\end{array}$ & $\begin{array}{l}2 \\
0 \\
0\end{array}$ & $\begin{array}{r}18 \\
9 \\
2 \\
29 \\
10\end{array}$ & $\begin{array}{r}9 \\
11 \\
11\end{array}$ \\
\hline
\end{tabular}

There were no significant differences between the groups. 


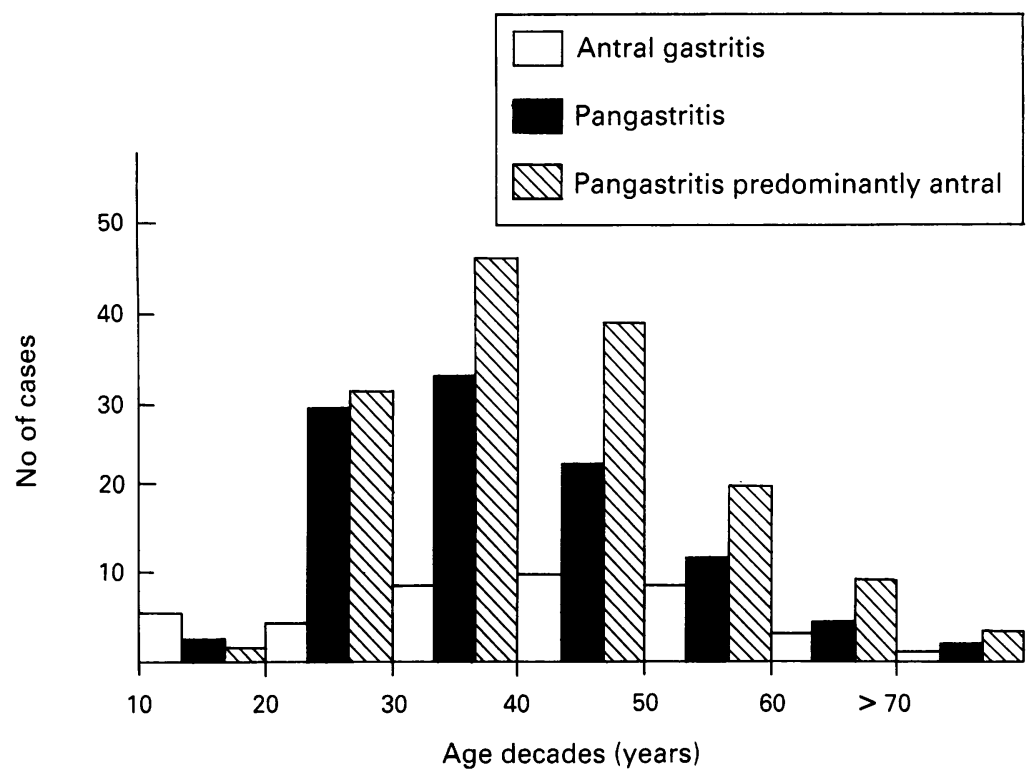

Figure 4 The main topographical patterns of Helicobacter associated gastritis in relation to the age of patients (decade) in 294 patients with ulcer and non-ulcer dyspepsia.

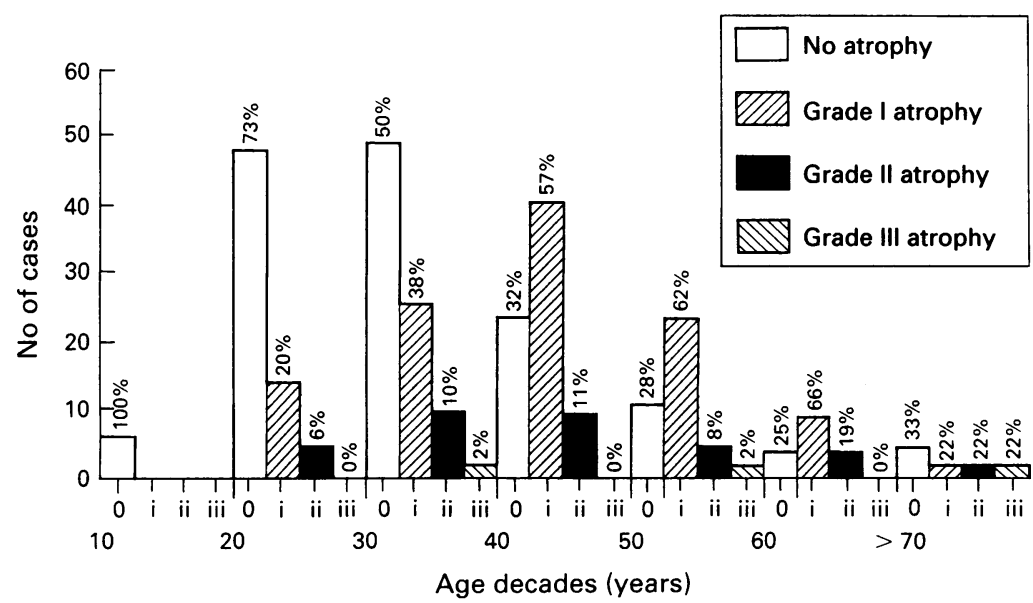

Figure 5 Atrophic and non-atrophic gastritis in antral biopsy specimens in relation to the age of patients (decade) from 294 subjects with ulcer and non-ulcer dyspepsia.

Table 4 Prevalence and distribution of $H$ pylori in antral type and body type gastric mucosa from Helicobacter associated gastritis in 294 patients with ulcer and non-ulcer dyspepsia

\begin{tabular}{llllll}
\hline & $\begin{array}{l}\text { Antrum } \\
\text { and body } \\
\text { equal } \\
\text { grades }\end{array}$ & $\begin{array}{l}\text { Antrum } \\
\text { and body } \\
\text { predominantly } \\
\text { antral }\end{array}$ & $\begin{array}{l}\text { Antrum } \\
\text { and body } \\
\text { predominantly } \\
\text { corporal }\end{array}$ & $\begin{array}{l}\text { Antral } \\
\text { only }\end{array}$ & $\begin{array}{l}\text { Corporal } \\
\text { only }\end{array}$ \\
\hline $\begin{array}{l}\text { No of patients } \\
\text { Percentage }\end{array}$ & 164 & 92 & 17 & 19 & 2 \\
\hline
\end{tabular}

*The predominance is determined by one-fold difference for $H$ pylori grades between antrum and body.
Table 6 Grades of intestinal metaplasia in antral and body mucosa in 294 patients with $H$ pylori associated gastritis

\begin{tabular}{lclll}
\hline Grade & $\begin{array}{l}\text { Antrum } \\
\text { only }\end{array}$ & $\begin{array}{l}\text { Body } \\
\text { only }\end{array}$ & $\begin{array}{l}\text { Antrum } \\
\text { and body }\end{array}$ & Percentage \\
\hline Grade I & 22 & 2 & 0 & 8 \\
Grade II & 5 & 0 & 0 & 2 \\
Grade III & 1 & 0 & 1 & 1 \\
Total & $28^{\star}$ & $2 \dagger$ & 1 & 11 \\
\hline
\end{tabular}

p value: ${ }^{\star} v+\mathrm{p}<0.0001$

Gastric atrophy of all grades was seen in 160 out of 294 (54\%) patients with $H$ pylor associated gastritis compared with 14 out of $24(58 \%)$ of patients with idiopathic gastritis (not significant). In $H$ pylori associated gastritis atrophy was seen in 114 out of 294 (39\%) patients in the antrum compared with three out of $294(1 \%)$ in the body $(p<0.0001)$. Atrophy in both antrum and body was seen in 43 out of $294(15 \%)$ patients and was lower than that seen in the antrum $(p<0.0001)$ and higher than that seen in the body ( $p>0.0001$ ).

Figure 5 shows all types of non-atrophic and atrophic gastritis in relation to the age groups in the antral biopsy specimens of patients with Helicobacter associated gastritis. Non-atrophic gastritis was the main pattern in the first four decades of life. Grade I atrophy was the most common type in patients between the third and sixth decades of life. Grades II and III increased with the increased age of the patients.

The distribution of intestinal metaplasia in Helicobacter associated gastritis is shown in table 6. Intestinal metaplasia was seen in the antrum only in 28 patients out of 294 , in the corpus only in two patients, and in both antrum and corpus in one patient out of 294 with $H$ pylori associated gastritis.

Table 7 shows the mean scores of $H$ pylori, atrophy, and intestinal metaplasia in nonulcer dyspepsia, duodenal ulcer, and gastric ulcer. There was no significant difference in the $H$ pylori grades in antrum or corpus among all clinical conditions. However, atrophy was more common in both antrum and corpus in patients with gastric ulcer than in patients with duodenal ulcer ( $p<$ $0.002, \mathrm{p}<0.015$, respectively) and patients with non-ulcer dyspepsia $(p<0.002, p=$ NS, respectively). Intestinal metaplasia was similarly higher in the antrum in patients with a gastric ulcer than in those with duodenal

Table 5 Grades of atrophy in Helicobacter associated gastritis (294) in comparison with idiopathic gastritis (24) in 337 patients with ulcer and non-ulcer dyspepsia

\begin{tabular}{|c|c|c|c|c|c|c|c|c|c|c|}
\hline & \multicolumn{5}{|c|}{ Helicobacter associated gastritis } & \multicolumn{5}{|c|}{ Idiopathic gastritis } \\
\hline & Antrum & Body & $\begin{array}{l}\text { Antrum } \\
\text { and } \\
\text { body }\end{array}$ & Total & $\%$ & Antrum & Body & $\begin{array}{l}\text { Antrum } \\
\text { and } \\
\text { body }\end{array}$ & Total & $\%$ \\
\hline $\begin{array}{l}\text { Grade O } \\
\text { Grade I } \\
\text { Grade II } \\
\text { Grade III } \\
\text { All grades/site } \\
\text { Per cent/site }\end{array}$ & $\begin{array}{r}93 \\
19 \\
2 \\
114 \\
39\end{array}$ & $\begin{array}{l}3 \\
0 \\
0 \\
3 \\
1\end{array}$ & $\begin{array}{r}30 \\
11 \\
2 \\
43 \\
15\end{array}$ & $\begin{array}{r}134 \\
126 \\
30 \\
4 \\
160\end{array}$ & $\begin{array}{c}46 \\
43^{\star} \\
10 \dagger \\
1 \neq \\
54+t\end{array}$ & $\begin{array}{r}9 \\
1 \\
0 \\
10 \\
42\end{array}$ & $\begin{array}{l}0 \\
1 \\
0 \\
1 \\
4\end{array}$ & $\begin{array}{r}0 \\
2 \\
1 \\
3 \\
12\end{array}$ & $\begin{array}{c}10 \\
9 \star \star \\
4 \pi \\
1 \neq \neq \\
140\end{array}$ & $\begin{array}{r}42 \\
37 \\
17 \\
4 \\
58\end{array}$ \\
\hline
\end{tabular}


Table 7 Scores of $H$ pylori, atrophy, and intestinal metasplasia in three clinical conditions non-ulcer dyspepsia, duodenal ulcer, and gastric ulcer in 294 patients with $H$ pylori associated gastritis

\begin{tabular}{|c|c|c|c|c|c|c|c|}
\hline \multirow{2}{*}{$\begin{array}{l}\text { Clinical } \\
\text { condition }\end{array}$} & \multirow{2}{*}{$\begin{array}{l}\text { Total } \\
\text { No of } \\
\text { patients }\end{array}$} & \multicolumn{2}{|c|}{ Mean score of $H$ pylori } & \multicolumn{2}{|c|}{ Mean score of atrophy } & \multicolumn{2}{|c|}{$\begin{array}{l}\text { Mean score of } \\
\text { intestinal metasplasia }\end{array}$} \\
\hline & & Antrum & Body & Antrum & Body & Antrum & Body \\
\hline $\begin{array}{l}\text { Non-ulcer dyspepsia } \\
\text { Dudenal ulcer } \\
\text { Gastric ulcer }\end{array}$ & $\begin{array}{r}197 \\
79 \\
18\end{array}$ & $\begin{array}{l}1.53^{\star} \\
1.27 \dagger \\
1.33+t\end{array}$ & $\begin{array}{l}1 \cdot 18 \ddagger \\
0 \cdot 88 \pm \ddagger \\
1 \cdot 06^{\star \star}\end{array}$ & 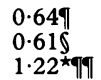 & $\begin{array}{l}0 \cdot 22^{\circ} \\
0 \cdot 08^{\circ} \\
0 \cdot 28^{\|}\end{array}$ & $\begin{array}{l}0.13^{\infty} \\
0.11^{\infty} \\
0.33^{\infty}\end{array}$ & $\begin{array}{l}0.04 \\
0.00 \\
0.00\end{array}$ \\
\hline
\end{tabular}

ulcer $(\mathrm{p}<0.02)$ and non-ulcer dyspepsia $(\mathrm{p}<0.02)$.

\section{Discussion}

The biopsy specimens used for this study were collected from patients in developing countries, from four cities in the northern region of the UAE, to give a representative sample of the heterogeneous population currently living there. The study has shown no significant variation in the prevalence of $H$ pylori in gastric biopsy specimens among populations of different ethnic origins. The colonisation rates of $H$ pylori varied between 87-93\% (mean 90\%). Most other authors have reported results comparable with those found in this study. ${ }^{9-12}$

The results have also shown that in duodenal ulceration the gastric mucosa is colonised by $H$ pylori in $99 \%$ of cases. However, in patients with gastric ulcer the colonisation rate $(78 \%)$ was significantly lower ( $p<$ 0.0001 ). Dixon reviewed 12 studies from European and other developed and developing countries, and reported a colonisation rate of $\mathrm{H}$ pylori of $93 \%$ for patients with duodenal ulcer and $80 \%$ for patients with gastric ulcer. ${ }^{7}$ A prevalence of $100 \%$ in patients with duodenal ulcer has been reported in one study from the Ivory Coast. ${ }^{26}$

$H$ pylori associated gastritis was the most common form of gastritis encountered in this study and accounted for $87 \%$ compared with $80 \%$ in patients from developed countries. ${ }^{27-28}$ The next largest group was idiopathic gastritis $(7 \cdot 1 \%)$ and although no serological tests for $H$ pylori were performed in patients of this group, some of these cases may have been due to previous infection with $H$ pylori. ${ }^{29}$ The development of gastric atrophy, which is higher in this group compared with $H$ pylor associated gastritis and intestinal metaplasia, may have led to the disappearance of $H$ pylori organisms within gastric biopsy specimens from some patients in this group.

Bile associated and drug associated reactive gastritis accounted together for $4.8 \%$ of the cases compared with $15 \%$ in patients from developed countries. ${ }^{23}$ In general, special forms of chronic gastritis accounted for $0.9 \%$ of the cases, representing a very small group of chronic gastritis. Lymphocytic gastritis is a newly described entity with one large study reporting an incidence of $1.4 \% .{ }^{25}$ In this study $0.6 \%$ of the cases showed evidence of lymphocytic gastritis.

In $93 \%$ of the patients $H$ pylori organisms were seen in both antrum and body mucosa.
Infection of antral mucosa only by $H$ pylor was observed in $6 \%$ of the cases while infection of the corporal mucosa only was seen in $1 \%$ of the cases. This indicates that $H$ pylori is likely to be missed in $6 \%$ of cases if the biopsy specimens included body-type gastric mucosa only, and in $1 \%$ of cases if the biopsy specimens were taken from the antrum only. Thus taking two biopsy specimens from the antrum and body of the anterior and posterior walls of the stomach ${ }^{21}$ will largely eliminate sampling error for detecting $H$ pylori. Antral mucosa is the main target for $H$ pylori colonisation. Similar results have been reported by other workers. ${ }^{30}$

The study has shown that $H$ pylori associated gastritis is accompanied by atrophy in $54 \%$ of the cases (of these $80 \%$ were grade I, $18 \%$ grade II, and $2 \%$ grade III). This is not surprising, as epidemiological studies from developing countries ${ }^{812}$ have suggested that the acquisition of infection by $H$ pylori is common at an early age of life, compared with lower incidences in populations from developed countries. ${ }^{6}$ The low percentage of grade III atrophy indicates that progression of atrophy from grade I to grade II and grade III is very small. Ihamaki et al found that in $42 \%$ of Finnish subjects with specific gastritis, atrophic gastritis developed over three decades. ${ }^{31}$ They found that antral mucosa often regressed histologically whereas superficial body gastritis often progressed towards atrophy.

In another study Sipponen et al described three topographic patterns of gastritis with atrophy in the same populations: antral gastritis with atrophy $(50 \%)$; corporal gastritis with atrophy (17\%); and pangastritis with atrophy (33\%). Three topographic patterns of $H$ pylor associated gastritis with atrophy were encountered in this study: antral gastritis with atrophy (39\%); pangastritis with atrophy $(15 \%)$; and chronic corporal gastritis with mild atrophy, representing only a minor proportion $(1 \%)$ of the patients in this study. This indicates that most cases of gastritis with atrophy are linked to the acquisition of $H$ pylori infection.

In developed countries atrophic body gastritis can be seen in three subtypes. The first is autoimmune associated gastritis which is a rare cause of corporal atrophy ${ }^{32}$ and is associated with pernicious anaemia. ${ }^{33-35}$ The second type of atrophic corporal gastritis can be seen in some patients with $H$ pylori infection and may represent an end stage of $H$ pylori associated superficial gastritis. ${ }^{29}$ The third type may 
be seen as a part of severe pangastritis, with atrophy as a consequence of $H$ pylori infection. ${ }^{3}$ The data from this study have shown a very low incidence of corporal gastritis with atrophy associated with $H$ pylori infection $(1 \%)$. None of the patients has shown histological evidence of autoimmune associated corporal gastritis. Thus corporal gastritis with atrophy represents a small part of Helicobacter associated gastritis, and occurred alone (1\%) or in combination with atrophic antral gastritis (15\%).

Correa described three topographic patterns of chronic atrophic gastritis: diffuse corporal, which occurs mainly in northern Europe; diffuse antral, which occurs in urban centres; and multifocal atrophic gastritis, which occurs in northern Europe, China, Japan and the Andes. ${ }^{18}$ As the risk of carcinoma of stomach is the lowest in the second pattern (atrophy of the antrum), then it is tempting to suggest that the risk of gastric carcinoma in the population studied would be far less than in the populations of northern Europe, Japan, and China.

In this study intestinal metaplasia occurred in $11 \%$ of the cases compared with $25 \%$ of cases reported by other workers from developed countries. ${ }^{36}$ Intestinal metaplasia was of grade $I$ and confined to the antrum in most cases $(9 \cdot 5 \%)$.

This study has shown no significant differences in the topographic patterns of $H$ pylori associated gastritis in non-ulcer dyspepsia, duodenal ulcer, and gastric ulcer. Differences in the patterns of gastritis in peptic ulcer diseases have been reported by some authors. ${ }^{7} 378$ However, the prevalence of glandular atrophy and intestinal metaplasia were higher in patients with gastric ulcer than in those with duodenal ulcer. The findings agree with those reported by other workers. ${ }^{737}$

It is concluded that the prevalence of $H$ pylori is higher in the UAE than that reported from developed countries, and that $H$ pylori associated gastritis is the predominant type of gastritis. Helicobacter associated gastritis with atrophy, although representing $50 \%$ of the cases, mainly includes atrophy of grade I and a very small proportion of cases progressing to grade III atrophy. Intestinal metaplasia and gastric atrophy were more common in patients with gastric ulcer than duodenal ulcer.

1 Rauws EAJ, Langenberg W, Houthoff HJ, Zanen HC, Tytgat GNJ. Campylobacter pyloridis-associated chron active antral gastritis. Gastroenterology 1988;94:33-40.

2 Wyatt JI, Dixon MF. Campylobacter associated chronic gastritis. Pathol Annu 1990;25(Pt 1):75-89.

3 Sipponen P, Kekki M, Siurala M. The Sydney system: epidemiology and natural history of chronic gastritis. f Gastroenterol Hepatol 1991;6:244-51.

4 Goodwin CS, Armstrong JA, Marshall BJ. Campylobacter pyloridis, gastritis and peptic ulceration. F Clin Pathol pyloridis, gastritis

5 Blaser MJ. Helicobacter pylori and the pathogenesis of gastro-duodenal inflammation. F Infect Dis 1990;161: 626-33.

6 Graham DY. Helicobacter pylori: Its epidemiology and its role in duodenal ulcer disease. $f$ Gastroenterol Hepatol 1991;6:105-13.

7 Dixon MF. Helicobacter pylori and peptic ulceration: Histopathological aspects. F Gastroenterol Hepatol 1991; 6:125-30.

8 Klein PD, Graham DY, Gaillour A, Opekun A, Smith EO. Water source as risk factor for Helicobacter pylori infec- tion in Peruvian children. Lancet 1991;337:1503-6.

9 Marshall BJ, McGechie DB, Rogers PA, Glancy RJ Campylobacter pylori infection and gastroduodenal disease. Med $\mathcal{F}$ Aust 1985;142:439-44.

10 Britt DP, Barakat MH, Tungekar MF, Painchaud SM, Adlouni M, Kern K, et al. Helicobacter pylori in dyspeptic patients in Kuwait. $\mathcal{F}$ Clin Pathol 1990;43:987-91.

11 El-Guneid A, El-Sherif AM, Murray-Lyon IM, Zureikat N, Shousha S. Effect of chewing Qat on mucosal histology and prevalence of Helicobacter pylori in the histology and prevalence of Helicobacter pylori in the oesophagus, stomach and duodenum
patients. Histopathology 1991;19:437-43.

12 Al-Moagel MA, Evans DG, Abdul Ghani ME, Adams E, Evans DJ, Malaty HM, et al. Prevalence of Helicobacter (formerly Campylobacter) pylori infection in Saudi Arabia: Comparison of those with and without upper gastrointestinal symptoms. Am F Gastroenterol 1990;85 $944-8$.

13 Whitehead R, Truelove SC, Gear MWL. The histological diagnosis of chronic gastritis in fibreoptic gastroscope biopsy specimens. 7 Clin Pathol 1972;25:1-11.

14 Cheli R, Giacosa A. Chronic atrophic gastritis and mucosal atrophy: One and the same. Gastrointest Endosc 1983;29:23-5.

15 Strickland RG, Mackay IR. A reappraisal of the nature and significance of chronic atrophic gastritis. Dig Dis 1973; 18:426-40.

16 Glass GB, Pitchumoni CS. Atrophic gastritis. Hum Pathol 1975;6:219-50.

17 Kekki M, Siurala M, Varis K, Sipponen P, Sistonen P, Nevanlinna RH. Classification principles and genetics of chronic gastritis. Scand $\mathcal{f}$ Gastroenterol 1987;22(Suppl): chronic

18 Correa P. Chronic gastritis: A clinico-pathological classification. Am $\mathcal{f}$ Gastroenterol 1988;83:504-9.

19 Wyatt JI, Dixon MF. Chronic gastritis: a pathogenic approach. F Pathol 1988;154:113-24.

20 Stolte $M$, Heilmann $\mathrm{KL}$. New classification of gastritis. Leber Magen Darm 1989;19:220-6.

21 Price AB. The Sydney system: Histological division. f Gastroenterol Hepatol 1991;6:209-22.

22 Zaitoun AM. Use of Romanowsky type (Diff-3) stain for detecting Helicobacter pylori in smears and tissue detecting Helicobacter pylori in sm.

23 Sobala GM, King RFG, Axon ATR, Dixon MF. Reflux gastritis in the intact stomach. $f$ Clin Pathol 1990;43: 303-6.

24 Taha AS, Nakshabendi I, Lee FD, Sturrock RD, Russell RI. Chemical gastritis and Helicobacter pylori related gastritis in patients receiving non-steroidal antiinflammatory drugs: Comparison and correlation with peptic ulceration. $\mathcal{F}$ Clin Pathol 1992;45:135-9.

25 Haot J, Hamichi L, Wallez L, Mainguet P. Lymphocytic gastritis: a newly described entity: a retrospective endoscopic and histological study. Gut 1988;29:1258-64.

26 Biomande MI, Flejou JF, Potet F, Dago-Akribi A, Ouatlara $\mathrm{D}$, Kadjo $\mathrm{K}$, et al. Chronic gastritis and Helicobacter pylori infection on the Ivory Coast. A series of 277 symptomatic patients. Gastroenterologie Clinique et Biologique 1991;15:711-6.

27 Blaser MJ. Gastric Campylobacter-like organisms, gastritis and peptic ulcer disease. Gastroenterology 1987;93: 371-83.

28 Yardley JH, Paull G. Campylobacter pylori: A new recognised infectious agent in the gastrointestinal tract. $A m$ f Surg Pathol 1988;12(Suppl):89-99.

29 Karnes WEJ, Samlof IM, Siurala M, Kekki M, Sipponen P, Kim SWR, et al. Positive serum antibody and negative tissue staining for Helicobacter pylori in subjects with tissue staining for Helicobacter pylori in subjects with
atrophic body gastritis. Gastroenterology 1991;101: atrophic

30 Maaroos HI, Kekki M, Villako K, Sipponen P, Tamm A, Sadeniemi L. The occurrence and extent of Helicobacter pylori colonisation and antral and body gastritis profiles in Estonian population sample. Scand $\mathcal{F}$ Gastroenterol 1990; 25:1010-7.

31 Ihamaki T, Kekki M, Sipponen P, Siurala M. The sequelae and course of chronic gastritis during a 30 to 34 year bioptic follow-up study. Scand $\mathcal{f}$ Gastroenterol 1985;20: 485-91.

32 Strickland RG. Autoimmune gastritis. $f$ Gastroenterol Hepatol 1991;6:238-43.

33 O'Connor HJ, Axon ATR, Dixon MF. Campylobacterlike organisms unusual in type A (pernicious anaemia) gastritis. Lancet 1984;ii: 1091 .

34 Fléjou JF, Bahame P, Smith AC, Stockrugger RW, Rhode $\mathrm{J}$, Price AB. Pernicious anaemia and Campylobacter-like organisms: is the gastric antrum resistant to colonisation? Gut 1989;30:60-4.

35 Feng TL, Dooley CP, Dehesa M, Cohen H, Carmel R, Fitzgibbons PL, et al. Helicobacter pylori infection in pernicious anaemia: a prospective controlled study. Gastroenterology 1991;100:328-32.

36 Rugge M, Dimario F, Cassaro M, Baffa R, Farinati F, Rubio J, et al. Pathology of the gastric antrum and body associated with Helicobacter pylori infection in non ulcer patients: is the bacterium a promoter of intestinal ulcer patients: is the bacterium a promoter
metaplasia? Histopathology 1993;22:9-15.

37 Sipponen P, Seppala K, Aarynen M, Helske T, Kettunen P. Chronic gastritis and gastroduodenal ulcer; a case control study on the risk of coexisting duodenal or gastric ulcer in patients with gastritis. Gut 1989;30:922-9.

38 Trier JS. Morphology of the gastric mucosa in patients with ulcer diseases. Dig Dis 1976;21:138-40. 